\title{
The logic of populism. Consequences of the clash between complexity and simple thinking ${ }^{1}$
}

\author{
Georg Vobruba (vobruba@uni-leipzig.de) \\ Leipzig University, Germany
}

The clash between complexity and simple thinking is likely to cause populism, which imagines a personal relationship between politics and the whole "people". Populism is characterized by particular features that are logically related to each other, resulting in a dynamic from which it is hard to escape.

Keywords: Populism, Social complexity, "the people", Representative democracy, Simple thinking

\section{The populist constellation}

Populism results from the attempt to cope with the complexity of society with simple everyday thinking. The thesis is based on two conditions.

The first condition is that everyday thinking relies on a simple understanding of causality that follows the logic of action. What does logic of action mean? The actor anticipates the effect of his action and makes it the goal of action. Schütz and Luckmann (2003) state: Action takes place modo futuri exacti. One imagines the consequences of his action with the intention of producing these consequences (see also Simmel, 1900/1989, 354). One intention is the anticipation of the success of the action in connection with the will to produce it. Intention determines the logic of action, with the logical interpretation of the world being reinforced by language. The practical necessity to signal connections between actors and objects leads to the fact that the logic of action is represented in the syntax. How strongly and directly action shapes the formation of language can be seen from the fact that in the syntaxes of almost all languages the subject is arranged in front of the object (Dux, 2017, 288, 289). The subject stands in the sentence before the object, the intention comes before the effect, the cause precedes the effect.

In the logic of action, a fact has an intention as cause. There is a 1:1 ratio between intention (cause) and effect (effect). In the context of the logic of action, explaining therefore means attributing an effect to an action-guiding will as its cause. This understanding of causality follows the logic of action. I call this logic of everyday thinking "simple thinking" (Vobruba, 2019).

The second condition is that there is a secular tendency in social development from simpler to more complex relationships. This process is a result of the increasing range of "functional interdependencies" (Elias, 1969/1980, 351) in the spatial and temporal dimensions. This means that spatially and (therefore) temporally distant events become relevant for

\footnotetext{
${ }^{1}$ I presented some parts of this paper at a conference on the occasion of the 65th birthday of Maurizio Bach at the
} University of Passau and as guest lectures at the Europe University Flensburg and the University Lüneburg. 
each other. The consequences of this are ever longer "chains of causality" (Simmel) which become increasingly unclear for the actors. Drivers of this secular tendency are technical and social innovations that lead to an ever more intensive division of labour, increasing transnational trade, increasing mobility of production factors and of information (to decreasing costs). All this increases the complexity of society. Social behaviour is perceived as complex in particular when intentions lead to results that are qualitatively different from the intentions. In other words. The intentions are not reflected in the results. In sociology such processes are described as "emergences", and they are causally traced back to mechanisms which produce emergent effects. "Common to all usages of the term emergence in the social sciences is that it is only applied to effects produced unintentionally" (Mayntz, 2009, 144). Mechanisms cause something, but do not themselves embody intention. They interfere between intention and effect, they break intentions and are thus their antithesis; the opposite of an action-logical 1:1 coupling. The paradigm for this is the market. The degree of complexity of society increases to the extent that social facts are determined by mechanisms.

Social complexity becomes a problem when it penetrates and is felt in the people's immediate Lebenswelt. I call the clash of complex social conditions and simple thinking: the populist constellation. Processes of rapid social change, transnationalization, economic integration, migration, and the acceleration of information make the emergence of such a constellation probable. In this perspective, populism is inevitable.

\section{The promise of populism}

Populism has a strong affinity to Gemeinschaft as a model for the reorganization of society (Vobruba, 1986). It promises simple solutions in the face of complex, opaque social conditions. In this way populism reacts to a broadly shared attitude to life, namely the widespread feeling of a loss of control. The populist promise of simple solutions seems seductively comforting.

Populism follows the logic of action in personal relationships: The decisive factor is the will of those involved. For the right politics, therefore, only the right intentions are needed. And if something goes wrong, there are evil intentions behind it. Consequently, populists have a tendency to go with conspiracy theories. There may be simple solutions in individual cases, but populist politics normally offer sham solutions. But it would be mistaken to understand populist programs as simple lies. The promises of populism are not only believed by parts of the public. Most likely, many populist politicians act in honest conviction. They are rather authentically simple than simply cynical. They really believe that refugee flows are directed by George Soros, that high vegetable prices can be lowered with fines, and that sexual offences can be prevented by tightening penalties. But authenticity doesn't make things better, on the contrary.

"Populist" is not a term for this or that policy content. Populism is a special idea of how the formation of a political will takes place. In the logic of populism, it takes place in a direct relationship between the political elites and the electorate. Marine Le Pen's "Rassemblement National“ (formerly known as „Front National“) consistently promises "une véritable révolution de la proximité". The immediate relationship between the politician and the people indicates: The populist knows what people want and acts on their immediate behalf (Puhle, 1986, 12ff.).

This immediate relationship is a fiction with real consequences. It requires the construction of a unified counterpart to populist politics. It is the construction of homogenous "people" („das Volk") that enables the deceptive simplicity of populism, but the people as a uniform entity does not exist. People have different worldviews, preferences, concerns and interests. Populists have little inclination and talent to mediate between such different positions. Compromises are not yours. In the logic of populism, the different interests and 
desires in society are rather a kind of menu from which one chooses suitable starting points for one's own politics. Some desires are very suitable for this, others not at all. In this respect, populism is selective in its content as a concept of political order. It advocates antipluralism, anti-nationalism and scepticism against science, and it opposes the separation of powers. From this follows: Left-wing populism does not work. When the left adopts populist logic, they slip to the right.

\section{The fiction of "the people“}

Since the homogenous people is a fiction, the populist cannot in reality receive his political mandate from the people. In fact, it is the other way round. The populist first projects his political ideas into the fiction "people" and then refers to this people to legitimize his politics. The populist imagines the unity of the people and himself as its exclusive representative. That this is a fundamental element of populism can be seen in the reason why Viktor Orbán, as an opposition politician, stayed away from the sessions of the Hungarian parliament: the people cannot oppose themselves (Müller, 2016).

Antipluralism is the logical consequence where the fiction of the unified people comes up against the diversity of values, interests, etc. in real society. Those who do not fit into the fiction of uniformity are pushed aside, excluded. Following this logic, Turkish President Erdogan calls those who support the "People's Alliance" between the ultra-national MHP and its Islamic conservative AKP as "faithful, patriotic people" in the Communal election campaign 2019. On the other hand, those who follow the opposition "alliance of the nation" are in his eyes "supporters of a terrorist organization". This distinction is compelling in the logic of populism: apart from the claim to represent the authentic will of the people, deviant expressions of will have neither place nor meaning. Those who oppose the will of the people exclude themselves from the people.

\section{Internal and external restrictions}

In the logic of populism, the scope of action of politics is imagined as very broad in principle. The consequence of this is the tendency to place politics above the democratic separation of powers. It is equally imperative to populists that restrictions on the political scope for action, from within and from without, are fought against.

Internally, populist politics is directed against all institutions and instances that stand in the way of the direct relationship between the populist and the "people," i.e., against all instances that mediate between the interests within the population and elite politics, set framework conditions for politics, or control politics. There is therefore little room for interest groups, for the autonomy of central banks and courts, for independent expert knowledge and for critical journalism. That's why Recep Tayyip Erdogan is trying to scourge the Turkish central bank. That is why Donald Trump calls critical media and courts "enemy of the people". Hence the attempts of the Polish PiS government to bring the judiciary under political control. This is why populist politics fuel scientific scepticism, for example on the subject of global warming.

The downside of scepticism towards all mediation and control over authorities in politics is the populist preference for beer tents and - more modern - for social media communication. The attractiveness of twitter and co. is immediately apparent in the logic of populism: social media simulate an unmediated relationship between politics and people. Thus social media fit with the promise of populism.

When it comes to addressing the outside world, the logic of populism leads to the illusion of unlimited national sovereignty. Depending on the position of power in world politics, the illusion of sovereignty may result in the non-recognition of international institutions and a tactical relationship to loyalty to treaties, or in political isolationism with the risk of collective impoverishment. Great Britain's rhetoric of sovereignty, which has gotten out of 
hand, has led to Brexit. "Taking control back" was the slogan in the campaign for the Brexit, with which the desire for liberation from confusing transnational contexts was translated into politics. This was not matched by an understanding of the benefits of these contexts. No other populist illusory solution is currently doing such damage - not even remotely. Finally, populist politics is protected against transnational contexts by the construction of external enemies. President Erdogan, in view of the rapidly rising vegetable prices, demonstrates how internal problems can be linked to the construction of external enemies: "Concentrate on prices for bullets and not for tomatoes".

Central features of European integration are very much in line with the logic of populism. Firstly, it is an ideal opponent against whom one can present oneself as a defender of national sovereignty. Secondly, as an area of free personal mobility, the EU can be linked to fears of alienation - not only by refugees from outside Europe, but also by migration within the EU. Thirdly, the EU institutions stand in the way of the populist illusion of a direct relationship between the political elite and the people. It goes without saying that the EU protects rather than impairs the Member States' remaining room for manoeuvre in the international system; that Europe's ageing societies urgently need migration; and that the relationship between political leaders and people is a populist illusion. That is not the point. Their failure to cope with reality hardly questions populist politics. Why?

\section{Populism as a drug}

Populism has a drug effect. Populist policies that try to ignore complex interrelationships remain ineffective or make things worse: import duties cannot prevent the US trade deficit from rising further. Political appeals for patriotic support for the Turkish lira are intensifying the flight into euros and dollars. In the logic of populism, more of the same is being said; higher tariffs, more passionate appeals. There is hardly any escape from such vicious circles. This means that in the logic of populism there is a dynamic of radicalization.

It is likely that the populist constellation will last, for the mismatch between complex relationships and simple thinking is likely to increase. This constellation points at the main danger of populism: Populism always has the potential for gradual radicalization. In the logic of populism lies radical nationalism (Lepsius, 1966) and the turning away from representative democracy.

\section{References}

Dux, G. (2017). Die Evolution der humanen Lebensform als geistige Lebensform. Wiesbaden: Springer BS.

Elias, N. (1969/1980). Über den Prozeß der Zivilisation. Zweiter Band. Frankfurt a. M.: Suhrkamp.

Lepsius, M. R. (1966). Extremer Nationalismus. Strukturbedingungen vor der nationalsozialistischen Machtergreifung. Stuttgart, etc.: Kohlhammer.

Mayntz, R. (2009). Emergence in Philosophy and Social Theory. In: R. Mayntz, Sozialwissenschaftliches Erklären (133-155). Frankfurt a. M., New York: Campus.

Müller, W. (2016). What is populism? Philadelphia: University of Pennsylvania Press.

Puhle, H.-J. (1986). Was ist Populismus? In: H. Dubiel (Hg.), Populismus und Aufklärung (1232). Frankfurt a. M.: Suhrkamp. 
Schütz, A., Luckmann, T. (2003). Strukturen der Lebenswelt. Konstanz: UVK.

Simmel, G. (1900/1989). Philosophie des Geldes. Frankfurt a. M.: Suhrkamp.

Vobruba, G. (1986). Die populistische Anrufung der Gemeinschaft. In: H. Dubiel (Hg.), Populismus und Aufklärung (221-247). Frankfurt a. M.: Suhrkamp.

Vobruba, G. (2019). Die Kritik der Leute. Einfachdenken gegen besseres Wissen. Weinheim, Basel: Beltz Juventa. 